\title{
Microbial transglutaminase alters the immunogenic potential and cross-reactivity of horse and cow milk proteins
}

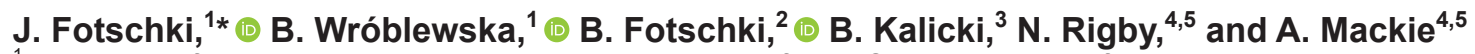 \\ ${ }^{1}$ Department of Immunology and Food Microbiology, Division of Food Science, Institute of Animal Reproduction and Food Research, \\ Polish Academy of Sciences, 10-748 Olsztyn, Poland \\ ${ }^{2}$ Department of Biological Function of Food, Division of Food Science, Institute of Animal Reproduction and Food Research, \\ Polish Academy of Sciences, 10-748 Olsztyn, Poland \\ ${ }^{3}$ Department of Pediatrics, Nephrology and Allergology, Military Institute of Medicine, 04-141 Warsaw, Poland \\ ${ }^{4}$ Institute of Food Research, Norwich NR4 7UA, United Kingdom \\ ${ }^{5}$ School of Food Science and Nutrition, University of Leeds, LS2 9JT, United Kingdom
}

\begin{abstract}
Horse milk is a valuable raw material and a very attractive alternative for scientific research to address the issue of cow milk (CM) allergy due to its protein profile. A decrease in immunoreactive properties can be achieved by thermal, enzymatic, and hydrolytic processing. Therefore, the aim of this study was to explore the possibility of reducing the immunoreactivity of horse milk proteins by microbial transglutaminase (TG) polymerization. To determine how TG linking alters immunoreactivity under simulated digestion of the examined milk, analyses were performed before, during, and after digestion. The dose-dependent (1, 10, and $100 \mathrm{U}$ ) effects of microbial TG on horse and cow milk were analyzed. A consecutive 3-stage digestion was simulated with salivary, gastric, and intestinal fluids. The effects of digestion were analyzed by SDS-PAGE, particle size analysis, and size-exclusion chromatography. Immunoreactivity was assessed using competitive ELISA ( $\beta$-lactoglobulin and $\alpha$-casein) and immunodot (sera from 7 patients aged 3 to 13 years who are allergic to CM proteins). Horse milk contained almost half of the amount of total proteins in CM. The dose $1 \mathrm{U} / \mathrm{g}$ of total milk protein changed the immunoreactivity of both cow and horse milk. With increasing TG doses, $\alpha$-casein immunoreactivity increased, and $\beta$-lactoglobulin decreased. After total digestion, horse milk was characterized by 2.4 -fold lower average $\operatorname{IgE}$ and 4.8-fold lower IgG reactivity than CM. We found that TG alters the IgE and $\operatorname{IgG}$ reactivity of CM after in vitro digestion. Horse milk was less reactive to $\operatorname{IgE}$ and IgG than was CM, with animal and patient sera.
\end{abstract}

Received July 15, 2019.

Accepted November 12, 2019.

*Corresponding author: j.fotschki@pan.olsztyn.pl
The effect of TG on immunoreactivity depends on enzyme quantity and milk protein type. The diet based on modified horse milk proteins could be an alternative for some patients with CM protein allergy; however, confirmation through clinical trials is needed.

Key words: simulated gastrointestinal digestion, cow milk protein allergy, microbial transglutaminase, horse milk

\section{INTRODUCTION}

Considering the increasing prevalence and nuisance of cow milk allergy (CMA), it is important to examine an alternative source of milk proteins and nutrients with similar immunological effects and nutritional value to cow milk (CM). Horse milk (HM) could be considered a substitute for CM, especially for people who suffer from CMA. Our previous study showed that HM proteins and CM proteins have similar immunoreactive epitopes (Fotschki et al., 2015a). The use of technological processing for modification of HM may lead to the development of a product with decreased immunogenic potential. Therefore, the aim of the present study was to explore the possibility of reducing the immunoreactivity of HM proteins through microbial transglutaminase (TG) cross-linking.

Cow milk allergy is characterized by an abnormal reaction of the immune system following contact with food containing CM proteins. Other than avoidance, no safe diet without the risk of side effects is available for people with CMA (Hochwallner et al., 2014). Among all foods, CM is often the first food introduced into the diet of infants, and CMA affects approximately $2.5 \%$ of children (Høst, 2002). Horse milk is currently of scientific interest, as the properties, components, and fractions of HM are highly similar to those of breast milk (Miranda et al., 2004; Potočnik et al., 2011). The administration of HM decreased serum IgE levels in mice 
sensitized to CM proteins (Fotschki et al., 2016). Fewer proteolytic-resistant peptides were absorbed from HM than from CM (Fotschki et al., 2015b). High digestibility and an optimum whey protein-to-caseins ratio make a compelling argument for selecting horse milk over the milk from other animals as a dietary substitute for humans (Uniacke-Lowe et al., 2010). The homology of the main proteins in $\mathrm{HM}$ and $\mathrm{CM}$ is approximately $62 \%$, significantly lower than the homology of the same proteins provided by the milk of other animals (buffalo, sheep, goat, pig, or donkey; Fiocchi et al., 2010). Due to its low protein homology with CM, HM may be characterized by different epitopes responsible for various immune reactions. Moreover, the concentration of caseins in HM is significantly lower than that in bovine milk (approx. 55 vs. $80 \%$ of total protein, respectively; Uniacke-Lowe et al., 2010). Due to cross-reactivity, the antibodies present in the serum of people with food allergies can interact with particular proteins that have structures similar to that of the allergen. Consistent with the data from Businco et al. (2000), HM is tolerated by $96 \%$ of studied children with CMA, and with appropriate modifications, HM can be regarded as a good substitute for CM for most children with severe IgE-mediated CMA.

A considerable number of scientific studies have attempted to reduce the antigenicity of food proteins by implementing different technologies such as polymerization, heat treatment, hydrolysis, fermentation, high-pressure processing, and microwave radiation (Sabadin et al., 2012; Wróblewska et al., 2016; Golkar et al., 2019). Transglutaminase cross-linking is a safe modification with no identified safety concerns with regard to allergenicity, according to the requirements of the 2001 FAO/WHO Decision Tree (Pedersen et al., 2004). Currently, TG is commonly used in the food industry as a protein cross-linking factor and to change some properties, such as texture, solubility, viscosity, gelation, and water retention capacity (Kieliszek and Misiewicz, 2014). According to the literature, microbial TG may significantly affect the digestibility and immunoreactivity of proteins and protein-based products (Cabrera-Chávez et al., 2009; Giosafatto et al., 2012; Wróblewska et al., 2013). Moreover, TG polymerization has been reported to reduce the immunoreactivity of some proteins known as severe milk allergens (Wróblewska et al., 2009). In contrast to cow, sheep, goat, and human breast milk, studies have reported the absence of a TG inhibitor in HM (de Jong et al., 2003); therefore, the effect of TG on the immunoreactivity of HM proteins seems to be worth studying. The effect of TG on CM has been previously studied (Olivier et al., 2012; Villas-Boas et al., 2012). To the knowledge of the present authors, no studies investigating the effect of
TG on the immunogenic potential of HM proteins have been conducted to date.

The enzymatic reactions that occur in the gastrointestinal tract cause hydrolysis of food components, exposing the collection of antigens that affect the immune system. Stability in intestinal and gastric fluids is associated with the intrinsic allergenicity of many proteins (Huby, 2000). The resistance of an allergenic food protein to in vivo digestion increases its potential to cause an allergic reaction in susceptible individuals (Schnell and Herman, 2009). Assessment of food allergens requires the use of both digestion and immunological assays to ensure the safety of milk proteins for consumers, taking into account the effects of the food matrix. Therefore, the determination of the influence of HM protein digestion previously modified by enzymatic reactions is a key issue to understanding the effects of new types of diets containing HM for allergic individuals in the future.

\section{MATERIALS AND METHODS}

\section{Samples}

Milk was collected from mares (Wielkopolski breed, $\mathrm{n}=6$, Genactiv Co., Poznań, Poland) and cows (Aberdeen breed, $\mathrm{n}=6$, Norwich, UK). After the animals were milked, aliquots of fresh milk were immediately chilled to $4^{\circ} \mathrm{C}$ and kept frozen at $-20^{\circ} \mathrm{C}$. The samples were heated for $10 \mathrm{~min}$ at $125^{\circ} \mathrm{C}$ to increase the availability of the enzyme to the substrate, incubated with microbial Ajinomoto Activa (Ajinomoto, Paris, France) TG for dairy use (activity $100 \mathrm{U} / \mathrm{g} ; 37^{\circ} \mathrm{C}, 18 \mathrm{~h}$ ) at different doses (1 U, $10 \mathrm{U}$, and $100 \mathrm{U}$ per $1 \mathrm{~g}$ of protein), and chilled to $4^{\circ} \mathrm{C}$. Protein determination was carried out using the Coomassie Plus Protein Assay Reagent (Thermo Fisher Scientific, Waltham, MA) using BSA as a standard (Bradford, 1976). Samples were stored at $-20^{\circ} \mathrm{C}$. The chemical composition of HM was analyzed using a MilkoScan FT2 Infrared Milk Analyzer (Foss, Hillerød, Denmark).

\section{In Vitro Gastrointestinal Digestion}

Sample digestion was carried out simultaneously, using the consensus static in vitro digestion protocol as previously described (Minekus et al., 2014) but without addition of salivary amylase. The following 3 consecutive stages of digestion were simulated: oral digestion, gastric digestion (GD), and intestinal digestion (ID). The digestion process was performed on 5 -mL samples. Briefly, in the oral phase, the suspensions were mixed with simulated salivary fluids $(50: 50 \mathrm{vol} / \mathrm{vol})$ to a final volume of $10 \mathrm{~mL}$. Porcine pepsin (P700, Sigma-Aldrich, 
Steinheim, Germany) and simulated gastric fluid were added to achieve a concentration of $2,000 \mathrm{U} / \mathrm{mL}$ in the final GD mixture. The samples were placed in a water bath with a magnetic stirrer for $2 \mathrm{~h}$ at $37^{\circ} \mathrm{C}$ (gastric digestion for $2 \mathrm{~h}, 2 \mathrm{GD}$ ) To simulate the intestinal phase of digestion, $2.5 \mathrm{~mL}$ of gastric chyme was mixed $1: 1$ with simulated intestinal fluid to a final volume of 5 $\mathrm{mL}$, and pancreatin (P7545, Sigma-Aldrich) was added to the digestion mixture to obtain the final mixture of $100 \mathrm{U} / \mathrm{mL}$ based on trypsin activity. Then bile (B8631, Sigma-Aldrich) was added to a final concentration of $10 \mathrm{~m} M$ in the final mixture, and the samples were incubated again for $2 \mathrm{~h}(2 \mathrm{GD}$ + intestinal digestion for $2 \mathrm{~h}$, 2ID). The samples were immediately frozen to stop the reaction. The obtained digested samples were used for the subsequent analysis.

\section{SDS-PAGE Analysis}

We performed SDS-PAGE analyses according to the methodology of Laemmli (1970), using NuPAGE 4 to $12 \%$ Bis-Tris gels (Invitrogen, Paisley, UK) with 2-( $N$-morpholino)ethanesulfonic acid running buffer (Invitrogen, NP0002-02) according to the manufacturer's instructions. Mark12 Molecular Weight Standard (Invitrogen, LC5677) was used as the molecular mass standard, and gels were stained using a Coomassiebased stain (Invitrogen, SimplyBlue SafeStain). After destaining, the gels were scanned using a Pharos FX Plus Imager and analyzed using Quantity One software v. 4.6.1 (Bio-Rad, Hercules, CA).

\section{Size-Exclusion Chromatography (SEC)}

The sample solutions were separated by size-exclusion chromatography (SEC) on a BioSep-SEC-S 2000 column (Phenomenex, Torrance, CA) attached to an HPLC system (Shimadzu Prominence; Shimadzu Corp., Kyoto, Japan). A solution containing $50 \mathrm{~m} M$ monosodium dihydrogen orthophosphate, $150 \mathrm{mM} \mathrm{NaCl}$, and $0.01 \%$ sodium azide at a $\mathrm{pH}$ of 7.0 was used as an eluant buffer. All the samples were filtered through a $0.22-\mu \mathrm{m}$ filter. The sample injection volume was 10 $\mu \mathrm{L}$, and the nominal flow rate was $0.4 \mathrm{~mL} / \mathrm{min}$. The retention time was interpolated to molecular weight $(\mathrm{kDa})$ according to molecular standards of the proteins. Undigested samples were centrifuged (15 min at 135 $\times g, 10^{\circ} \mathrm{C}$, Centrifuge $5424 \mathrm{R}$, Eppendorf, Hamburg Germany) and filtered $(0.22 \mu \mathrm{m})$.

\section{Particle Size Analysis}

Samples were analyzed with an LS 13320 laser diffraction particle size analyzer with the Universal Liquid
Module (Beckman Coulter, Brea, CA). For determination of the size distribution, a refractive index of 1.462 (that of milk fat) was used.

\section{Immunoreactivity of Milk Proteins: Competitive ELISA}

In this study, the term "immunoreactivity" refers to the ability of an antibody to recognize a native protein or a hydrolyzed protein in CM or HM. The ELISA method was carried out according to a previously described method (Wróblewska et al., 2009; Fotschki et al., 2015a). The immunoreactivity levels of samples were compared using the antibodies targeting the $\mathrm{CM}$ proteins $\beta$-LG and $\alpha-\mathrm{CN}$. Microtiter plates were coated with antigen ( $\alpha$-CN C6780, $\beta$-LG L3908, SigmaAldrich) diluted in $0.05 M$ carbonate buffer ( $\mathrm{pH} 9.6$ ) and incubated overnight at $4^{\circ} \mathrm{C}$. Then the samples or standard antigen and polyclonal rabbit antibodies were added and incubated $\left(37^{\circ} \mathrm{C}\right.$ for $\left.2 \mathrm{~h}\right)$. Animal sera were obtained every 2 wk from rabbits immunized 4 times. The single allergen concentration was $2.5 \mathrm{mg} / \mathrm{mL}$ per animal, emulsified with an equivalent amount of Freund's Adjuvant (Complete, Sigma-Aldrich F5881, at first immunization; Incomplete, F5506, during the next immunizations) to obtain a final concentration of $1 \mathrm{mg} /$ $\mathrm{mL}$. The wells were washed and filled with horseradish peroxidase-conjugated goat anti-rabbit IgG (A6154, Sigma-Aldrich). The reagent $3,3^{\prime}, 5,5^{\prime}$-tetramethylenbenzidine (T5525, Sigma-Aldrich) was used as a substrate solution. The plates were incubated $\left(37^{\circ} \mathrm{C}\right.$ for 15 to $30 \mathrm{~min}$ ), and the reaction was stopped by adding 2 $M \mathrm{H}_{2} \mathrm{SO}_{4}$. Absorption was measured at the wavelength of $450 \mathrm{~nm}$ using a Sunrise plate reader (Tecan, Männedorf, Switzerland). Immunoreactivity was calculated from the standard curves of protein antigens in CM. All analyses were carried out in triplicate, and average values were converted to concentration equivalents (in $\mu \mathrm{g}$ per $\mathrm{mL}$ ). A nonlinear adjustment was applied to the data obtained for each dilution from each rabbit serum. The adjusted model was a sigmoidal curve and was obtained with the GraphPad Prism program (version 5.0, GraphPad Software Inc., San Diego, CA).

\section{Immunodot}

Human serum samples were collected from 7 patients aged 3 to 13 years with history of CMA [approved by the Local Ethics Commission (2/2010)]. The bacterial proteins that reacted with total $\mathrm{IgG}$ and $\mathrm{IgE}$ were detected according to a previously described method (Markiewicz et al., 2016), with modifications. Briefly, the membranes with applied samples were incubated (120 min, room temperature) with Odyssey Blocking 
Buffer (pH 7.2 to 7.6, 927-40003, LI-COR Biosciences, Lincoln, NE). Samples were diluted with HM at a 1:4 (vol/vol) ratio and with $\mathrm{CM}$ at a 1:8 (vol/vol) ratio. Human sera were diluted $2 \times$ with Odyssey Blocking Buffer containing $0.1 \%$ Tween. Membranes were incubated overnight at $4^{\circ} \mathrm{C}$ and then incubated for $90 \mathrm{~min}$ at room temperature, with 2 types of secondary antibodies labeled with different fluorescent markers: a 700-nm dye (red channel) and an 800-nm dye (green channel). Commercially available goat anti-human IgG antibodies already conjugated with IRDye 800CW (926-32232, LICOR Biosciences) and mouse monoclonal anti-human IgE antibodies (I6510, Sigma-Aldrich) labeled using the IRDye 680RD Protein Labeling Kit (928-38072, LI-COR Biosciences) were used. The anti-human IgG and anti-human IgE secondary antibodies were diluted 1:5,000 and 1:500, respectively, with Odyssey Blocking Buffer (pH 7.2 to 7.6 ) containing $0.1 \%$ Tween 20 and $0.01 \%$ SDS. Signal detection was carried out with the Odyssey Infrared Imaging System (LI-COR Biosciences) using autoscan settings and LI-COR Image Studio software (version 2.0). ImageJ 1.52a (Wayne Rasband, National Institutes of Health, Bethesda, MD) was used for image analysis. The reaction between samples and human IgE and IgG was expressed by the dot intensity.

\section{Statistical Analysis}

We used Statistica software, version 10.0 (StatSoft Corp., Krakow, Poland), to determine whether variables differed among treatment groups. The results were statistically analyzed using one-way ANOVA and Duncan's multiple range test. Differences with $P \leq 0.05$ were considered significant. Data are expressed as the mean and standard error of the mean (SEM), except for the chemical composition and physical parameters, and the residual IgE and IgG reactivity of HM and CM are expressed as the mean and the standard deviation (SD) of the mean. The results are based on 3 replicates.

\section{RESULTS}

\section{Characterization of the Samples}

Table 1 shows the selected chemical components and physical parameters of HM and CM. Protein content in $\mathrm{HM}$ was 1.8 -fold lower than in $\mathrm{CM}$. The $\mathrm{HM}$ contained 1.5-fold lower concentration of lactose than did CM. The fat content in HM was 4.3-fold lower than that of CM. The SDS-PAGE electropherogram in Figure 1 shows the pattern of undigested samples of CM and HM with and without the addition of different doses of TG. As shown in lanes 1 and 2, CM and HM showed different protein compositions. Results showed that increasing doses of TG led to changes in the structure of the milk matrix and could increase disulphide bond formation. Based on the electrophoresis data, the addition of TG enhanced protein polymerization and agglomerate formation, especially in CM, in the range of 120 to $200 \mathrm{kDa}$. The cross-linking of proteins with $1 \mathrm{U}$ of TG was more clearly observed in CM samples than in HM samples. Under the polymerization with $100 \mathrm{U}$ of TG, new bands were detected that did not exist in the samples with the addition of 1 and $10 \mathrm{U}$ of TG, and the bands corresponded with the molecular weight of TG. Enzyme residues were observed due to the surplus of the enzyme relative to the protein substrate. We used SDS-PAGE to monitor enzymatic polymerization with TG; however, this method has some limitations in maximum separation. Therefore, polymers with high molecular weights $(>200 \mathrm{kDa})$ were not visible. Samples with $100 \mathrm{U}$ of TG were characterized by a streak in the upper part of the gel, due to the presence of high-molecular-mass conglomerates, which possibly could not get into the gel.

\section{Simulation of In Vitro Digestion}

To evaluate the effect of in vitro digestion on samples cross-linked with TG or control samples, we performed salivary, gastric, and duodenal digestion under simulated physiological conditions. The effects of digestion were analyzed using SDS-PAGE (Figure 2), particle size analysis (Figure 3), and SEC (Figure 4).

The results show that, upon gastric digestion of the studied samples, some proteins were partially intact. The use of the lowest enzyme dose did not result in the formation of fully cross-linked polymers, and we found no visible differences on the SDS-PAGE electropherograms of samples after gastric and total digestion (data not shown). A similar pattern was observed for CM and for CM with $10 \mathrm{U}$ of TG added (+10 U TG); however, the patterns of $\mathrm{HM}$ and $\mathrm{HM}+10 \mathrm{U}$ TG samples were different. In this analysis, the addition of $100 \mathrm{U}$ of TG to $\mathrm{CM}$ and $\mathrm{HM}$ changed the protein profiles in both matrixes. After total digestion, the analyzed samples

Table 1. Chemical composition and physical parameters of horse and cow milk (mean \pm SD)

\begin{tabular}{lcc}
\hline Parameter & Horse milk & Cow milk \\
\hline Total proteins $(\%)$ & $1.75 \pm 0.16$ & $3.23 \pm 0.23$ \\
Fat $(\%)$ & $0.64 \pm 0.20$ & $2.73 \pm 0.32$ \\
Lactose $(\%)$ & $7.12 \pm 0.39$ & $4.74 \pm 0.24$ \\
Urea $(\mathrm{mg} / \mathrm{L})$ & $375 \pm 0.12$ & $112 \pm 0.20$ \\
Freezing point $\left({ }^{\circ} \mathrm{C}\right)$ & $-0.56 \pm 1$ & $-0.55 \pm 1$ \\
Fat-free DM $(\mathrm{g} / \mathrm{L})$ & $9.61 \pm 0.19$ & $9.35 \pm 0.11$ \\
\hline
\end{tabular}




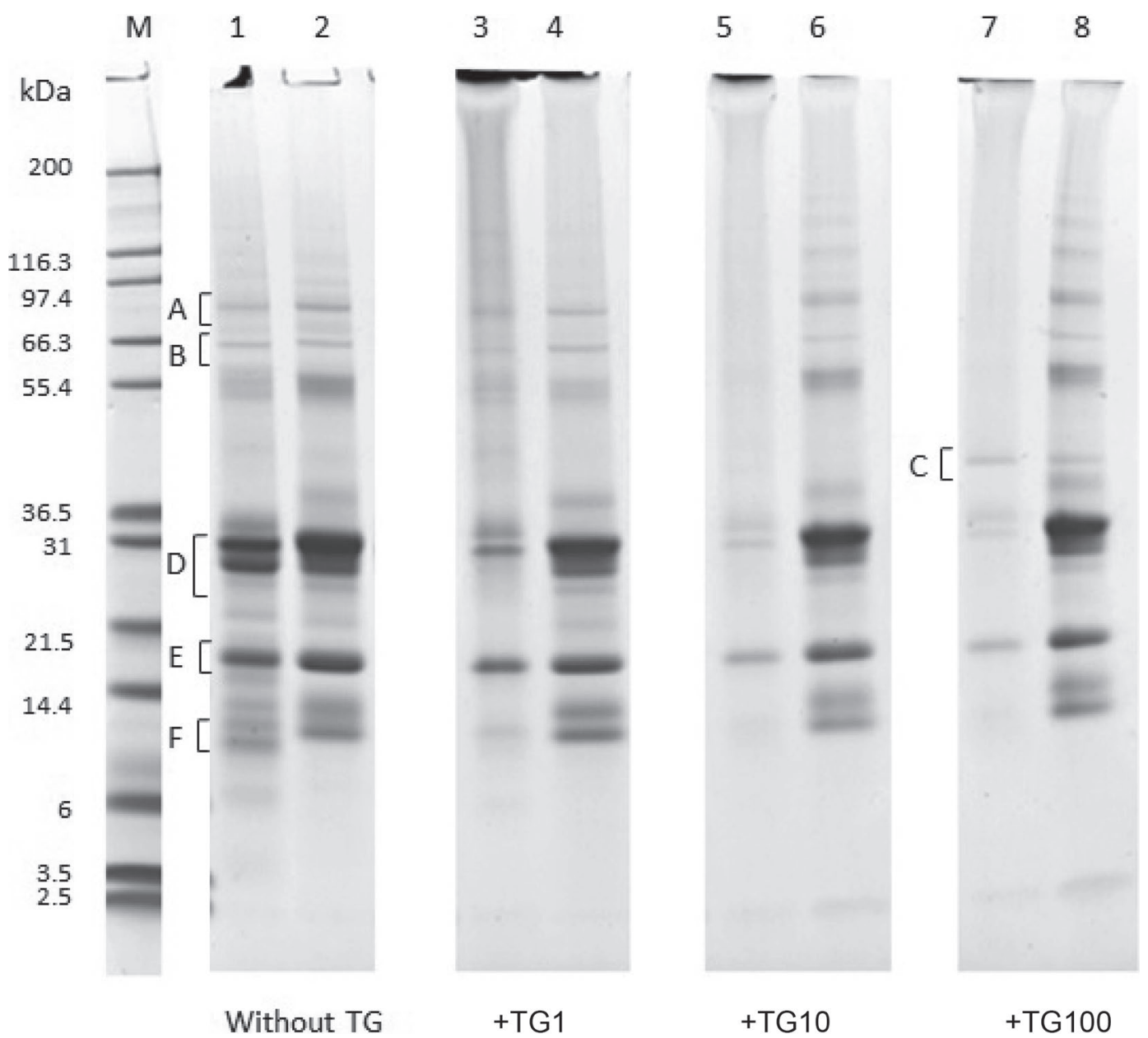

Figure 1. Electropherogram from SDS-PAGE of nondigested samples of horse milk (HM) and cow milk $(\mathrm{CM}) . \mathrm{M}=$ molecular marker; $1=$ raw $\mathrm{CM} ; 2=$ raw HM; $3=\mathrm{CM}+\mathrm{TG} 1 ; 4=\mathrm{HM}+\mathrm{TG} 1 ; 5=\mathrm{CM}+\mathrm{TG} 10 ; 6=\mathrm{HM}+\mathrm{TG} 10 ; 7=\mathrm{CM}+\mathrm{TG} 100 ; 8=\mathrm{HM}+\mathrm{TG} 100 ; \mathrm{TG}=$ Ajinomoto Activa (Ajinomoto, Paris, France) transglutaminase $(37.8 \mathrm{kDa})$; TG1, TG10, and TG100 = doses of TG (U) per $1 \mathrm{~g}$ of total protein. $\mathrm{A}=$ lactoferrin; $\mathrm{B}=\mathrm{BSA} ; \mathrm{C}=\mathrm{TG}$ residues; $\mathrm{D}=\alpha-, \beta$-, and $\kappa$-caseins; $\mathrm{E}=\beta$-LG; $\mathrm{F}=\alpha$-LA. Samples were diluted to $1 \mathrm{mg} / \mathrm{mL}$ of total protein content. Samples 3 through 8 were pretreated $\left(10 \mathrm{~min}\right.$ at $\left.125^{\circ} \mathrm{C}\right)$.

were degraded, and we found were no observed differences between samples.

The particle size distribution of CM and HM with different doses of microbial TG before and during in vitro gastrointestinal digestion are shown in Figure 3. The results showed that the introduction of covalent bonds between or within proteins or peptides affects the particle size distribution of CM and HM in a dose-dependent manner. Undigested HM contained 2 main fractions of particles with a size range of 0 to $1 \mu \mathrm{m}$ and 1 to $10 \mu \mathrm{m}$. Cow milk was mostly characterized by particles with a size from 1 to $20 \mu \mathrm{m}$. In undigested samples, the particle size clearly increased with increasing TG dose. Based on these results, it becomes apparent that the protein network formed after extensive cross-linking of proteins by TG results in tightly packed protein nanoparticles, also indicating intramolecular cross-linking. Compared with undigested samples, the samples digested with simulated salivary fluid and simulated gastric fluid showed decreases in the content of particles with a size 0.1 to $20 \mu \mathrm{m}$. After gastric digestion, the addition of TG to CM and HM samples increased the proportion of particles with a size range of 10 to $40 \mu \mathrm{m}$. This finding suggests that TG influenced the gastric digestibility of the studied samples, slowing digestion of the proteins. After gastric digestion, the aforementioned increase in the size of particles in samples with addition of $100 \mathrm{U}$ of TG could have been because of the poor breakdown of aggregates by pepsin.

The interpolated kinetic profile of the molecular weight fractions of undigested and digested $\mathrm{CM}$ and HM with different doses of TG is shown in Figure 4. The profiles of CM and HM samples were different, taking into account the undigested samples (I) and dur- 
ing $(\mathrm{A}, \mathrm{E})$ and after gastric digestion $(\mathrm{B}, \mathrm{F})$. A similar pattern of molecular weights was observed in these samples during $(\mathrm{C}, \mathrm{G})$ and after intestinal digestion $(\mathrm{D}, \mathrm{H})$. The undigested samples of $\mathrm{CM}$ were characterized mostly by fractions ranging from 10 to $100 \mathrm{kDa}$ and 500 to $1,000 \mathrm{kDa}$, whereas $\mathrm{HM}$ samples ranged from 10 to $30 \mathrm{kDa}$. After both 1 and $2 \mathrm{~h}$ of digestion, fewer fractions above molecular weight of $10 \mathrm{kDa}$ were found in HM than in CM. The addition of TG to both $\mathrm{CM}$ and HM caused a decrease in intensity due to the polymerization that occurred in samples. The results showed that each subsequent step of in vitro digestion caused an increase in the level of fractions corresponding to low molecular masses. During and after intestinal digestion, most $\mathrm{CM}$ and $\mathrm{HM}$ proteins were transformed into peptides of less than $10 \mathrm{kDa}$.

\section{Immunoreactivity with Animal Sera}

The ELISA results showed that in undigested HM and CM with increasing doses of the TG enzyme, the immunoreactivity of $\alpha-\mathrm{CN}$ was increased, and $\beta$-LG was decreased (Figure 5). The addition of TG, regardless of the dose, decreased the immunoreactivity of studied proteins in HM both during and after the gastric digestion step. The polymerization of $\mathrm{CM}$ proteins with a TG dose of $100 \mathrm{U}$ increased the immunoreactivity of $\alpha-\mathrm{CN}$ and $\beta-\mathrm{LG}$ during and after gastric digestion (Figure 6). Polymerization decreased the immunoreactivity of $\alpha-\mathrm{CN}$ in $\mathrm{HM}$ and increased the immunoreactivity of $\alpha-\mathrm{CN}$ in $\mathrm{CM}(10$ and $100 \mathrm{U}$ of TG) after $1 \mathrm{~h}$ of intestinal digestion and had no effect on $\mathrm{HM}$ and $\mathrm{CM}$ after total digestion. After 1 and 2 $\mathrm{h}$ of intestinal digestion, the immunoreactivity of HM increased in a dose-dependent manner and decreased in CM (1ID with 10 and $100 \mathrm{U}$ of TG; 2ID with all tested doses). During and after gastric digestion, and after 1 $\mathrm{h}$ of intestinal digestion, the immunoreactivity of $\alpha-\mathrm{CN}$ from CM was significantly higher than from HM. The differences in the immunoreactivity of $\alpha-\mathrm{CN}$ between samples after total digestion were negligible. The immunoreactivity of $\beta$-LG was significantly lower in all
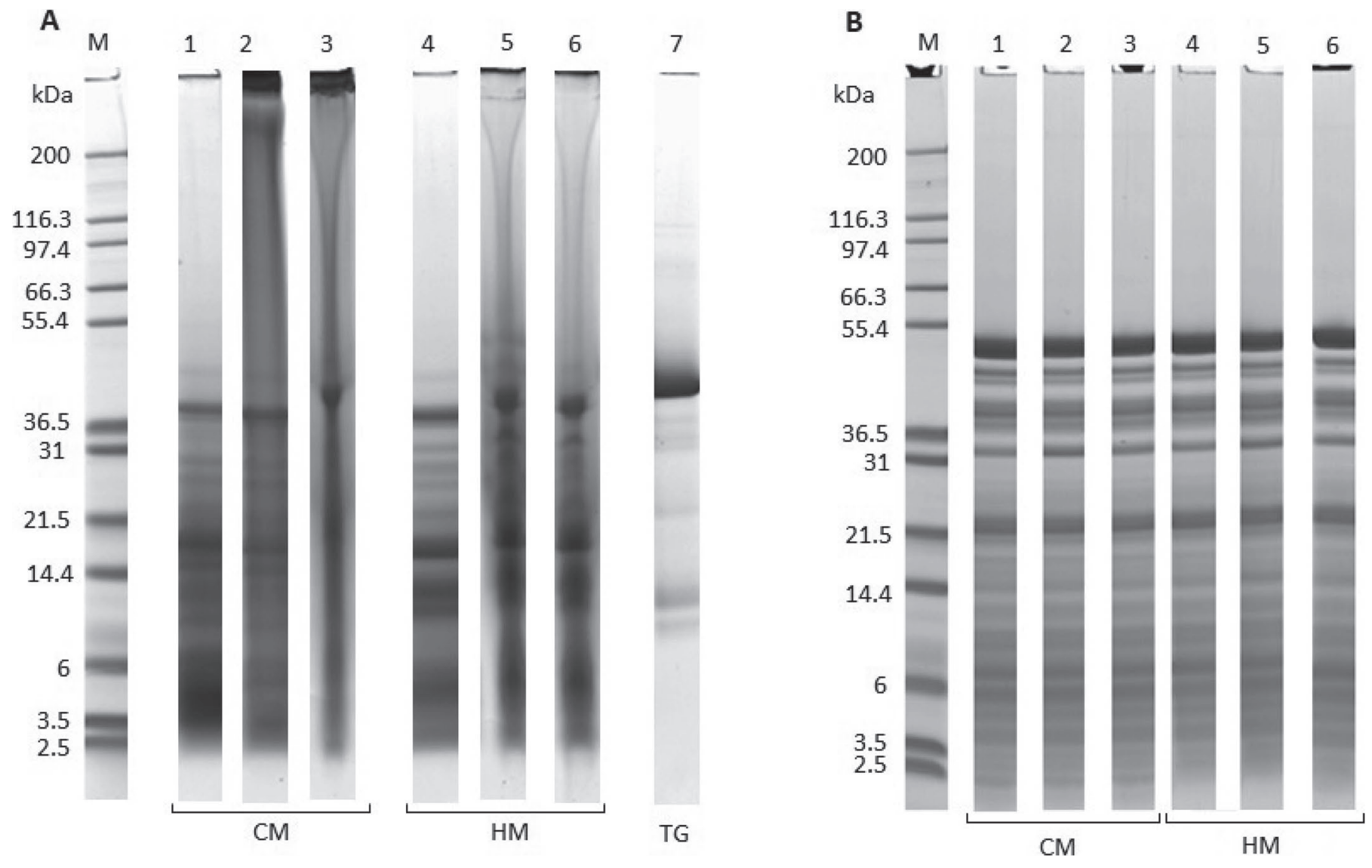

Figure 2. Electropherogram from SDS-PAGE of samples of horse milk (HM) and cow milk $(\mathrm{CM})$ after $2 \mathrm{~h}$ of gastric digestion $(\mathrm{A}: 1=\mathrm{CM}$; $2=\mathrm{CM}+\mathrm{TG} 10 ; 3=\mathrm{CM}+\mathrm{TG} 100 ; 4=\mathrm{HM} ; 5=\mathrm{HM}+\mathrm{TG} 10 ; 6=\mathrm{HM}+\mathrm{TG} 100 ; 7=$ nondigested TG) and total digestion $($ gastric and intestinal, B: $1=\mathrm{CM} ; 2=\mathrm{CM}+\mathrm{TG} 10 ; 3=\mathrm{CM}+\mathrm{TG} 100 ; 4=\mathrm{HM} ; 5=\mathrm{HM}+\mathrm{TG} 10 ; 6=\mathrm{HM}+\mathrm{TG} 100)$. $\mathrm{M}=$ molecular marker; TG $=$ Ajinomoto Activa (Ajinomoto, Paris, France) transglutaminase; TG10 and TG100 = dose of TG (U) per $1 \mathrm{~g}$ of total protein. 
tested HM samples than in $\mathrm{CM}$ after $1 \mathrm{~h}$ of gastric digestion. Surprisingly, after $2 \mathrm{~h}$ of gastric digestion, the $\beta-\mathrm{LG}$ immunoreactivity of $\mathrm{CM}+100 \mathrm{U}$ TG remained at a high level, in contrast to samples with lower doses of TG. However, after $1 \mathrm{~h}$ of intestinal digestion, $\mathrm{CM}+100$ U TG was characterized by a lower $\beta-L G$ immunoreactivity than $\mathrm{HM}+100 \mathrm{U}$ TG. Finally, the post-digestion $\beta$-LG immunoreactivity of CM was significantly higher than that of all tested HM samples.

\section{Immunodot with Human Sera}

Immunodot analyses were carried out to assess the $\operatorname{IgE}$ and $\operatorname{IgG}$ reactivity of $\mathrm{CM}$ and $\mathrm{HM}$ samples with and without TG before, during, and after digestion (Figure 7 and Table 2). Figure 7 shows the results of each sample normalized to the same amount of protein from different origins. All sera from patients were analyzed by immunodot technique and showed binding to individual CM proteins (Supplemental Figure S1; https:/ / doi.org/10.3168/jds.2019-17264). Various signal inten- sities from the $\operatorname{IgE}$ and $\operatorname{IgG}$ sera of individual patients were observed. Addition of TG did not change the average signal of undigested CM and HM. Significant differences in $\mathrm{IgE}$ and $\mathrm{IgG}$ dot intensity were observed between the $\mathrm{CM}$ and $\mathrm{CM}+100 \mathrm{U}$ TG samples after total digestion. The average $\operatorname{IgG}$ signal of the undigested raw $\mathrm{CM}$ was higher than that of the raw HM, and the signal of digested CM was higher than that of digested HM. After gastric digestion, a lower average signal was observed for $\mathrm{HM}$ and $\mathrm{HM}+100 \mathrm{U}$ TG than for $\mathrm{CM}$ and $\mathrm{CM}+100 \mathrm{U}$ TG. Table 2 shows the results of each sample normalized to the same volume of milk from different origins. Considering the average signals of both IgE and IgG, the TG cross-linking did not change the parameters of the undigested and gastrically digested $\mathrm{CM}$ and HM. Increased average $\operatorname{IgE}$ and $\operatorname{IgG}$ signals were observed for CM samples with TG after total digestion. The lowest average IgE intensity among the undigested products was observed for raw HM and IgG HM. The highest-value average $\operatorname{IgE}$ and $\operatorname{IgG}$ intensities among the non-digested products were observed in

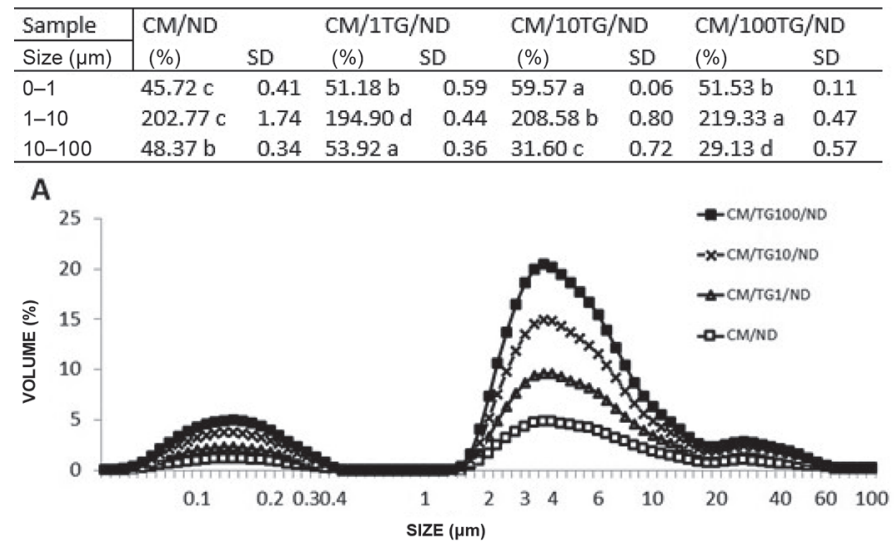

\begin{tabular}{l|llllllll}
\hline Sample & CM/2GD & \multicolumn{3}{|c}{ CM/1TG/2GD } & \multicolumn{3}{c}{ CM/10TG/2GD } & \multicolumn{2}{c}{ CM/100TG/2GD } \\
\cline { 1 - 4 } Size $(\mu \mathrm{m})$ & $(\%)$ & SD & $(\%)$ & SD & $(\%)$ & SD & $(\%)$ & SD \\
\hline $0-1$ & $32.09 \mathrm{a}$ & 0.91 & $27.42 \mathrm{~b}$ & 0.69 & $22.75 \mathrm{c}$ & 0.49 & $13.41 \mathrm{~d}$ & 0.32 \\
$1-10$ & $232.12 \mathrm{a}$ & 1.75 & $216.69 \mathrm{~b}$ & 1.49 & $201.26 \mathrm{c}$ & 1.23 & $170.40 \mathrm{~d}$ & 0.73 \\
$10-100$ & $35.79 \mathrm{~d}$ & 0.85 & $55.89 \mathrm{c}$ & 0.82 & $75.99 \mathrm{~b}$ & 0.79 & $116.19 \mathrm{a}$ & 0.73 \\
\hline
\end{tabular}

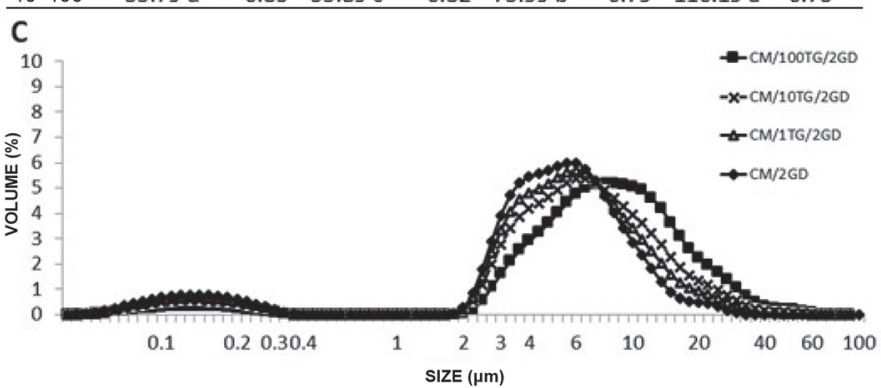

\begin{tabular}{|c|c|c|c|c|c|c|c|c|}
\hline Sample & \multicolumn{2}{|l|}{$\mathrm{HM} / \mathrm{ND}$} & \multicolumn{2}{|c|}{$\mathrm{HM} / 1 \mathrm{TG} / \mathrm{ND}$} & \multicolumn{2}{|c|}{$\mathrm{HM} / 10 \mathrm{TG} / \mathrm{ND}$} & \multicolumn{2}{|c|}{$\mathrm{HM} / 100 \mathrm{TG} / \mathrm{ND}$} \\
\hline Size $(\mu \mathrm{m})$ & $(\%)$ & & $(\%)$ & SD & $(\%)$ & SD & $(\%)$ & \\
\hline $0-1$ & $164.58 \mathrm{c}$ & 0.76 & $180.09 \mathrm{a}$ & 0.78 & $180.89 \mathrm{a}$ & 0.38 & $169.83 \mathrm{~b}$ & 0.62 \\
\hline $1-10$ & $122.33 \mathrm{a}$ & 1.47 & $111.54 b$ & 0.50 & $106.83 \mathrm{c}$ & 0.41 & $110.09 \mathrm{k}$ & 1.24 \\
\hline $10-100$ & $12.87 \mathrm{~b}$ & 0.67 & $8.37 \mathrm{c}$ & 0.90 & $12.28 \mathrm{~b}$ & 0.75 & $23.20 \mathrm{a}$ & 0.53 \\
\hline
\end{tabular}

\begin{tabular}{|c|c|c|c|c|c|c|c|c|}
\hline Sample & \multicolumn{2}{|l|}{$\mathrm{HM} / 2 \mathrm{GD}$} & \multicolumn{2}{|c|}{$\mathrm{HM} / 1 \mathrm{TG} / 2 \mathrm{GD}$} & \multicolumn{2}{|c|}{$\mathrm{HM} / 10 \mathrm{TG} / 2 \mathrm{GD}$} & \multicolumn{2}{|c|}{$\mathrm{HM} / 100 \mathrm{TG} / 2 \mathrm{GD}$} \\
\hline Size $(\mu \mathrm{m})$ & $(\%)$ & SD & $(\%)$ & SD & $(\%)$ & SD & $(\%)$ & SD \\
\hline $0-1$ & $0.00 \mathrm{~d}$ & 0.00 & $7.18 \mathrm{c}$ & 0.07 & $14.37 \mathrm{~b}$ & 0.14 & $28.73 a$ & 0.28 \\
\hline $1-10$ & $91.40 \mathrm{~d}$ & 0.62 & $109.68 \mathrm{c}$ & 0.72 & $127.97 \mathrm{~b}$ & 0.84 & $164.53 \mathrm{a}$ & 1.10 \\
\hline $10-100$ & $208.60 \mathrm{a}$ & 0.61 & $109.31 \mathrm{c}$ & 1.77 & $154.02 \mathrm{~b}$ & 0.93 & $106.74 \mathrm{c}$ & 1.54 \\
\hline
\end{tabular}
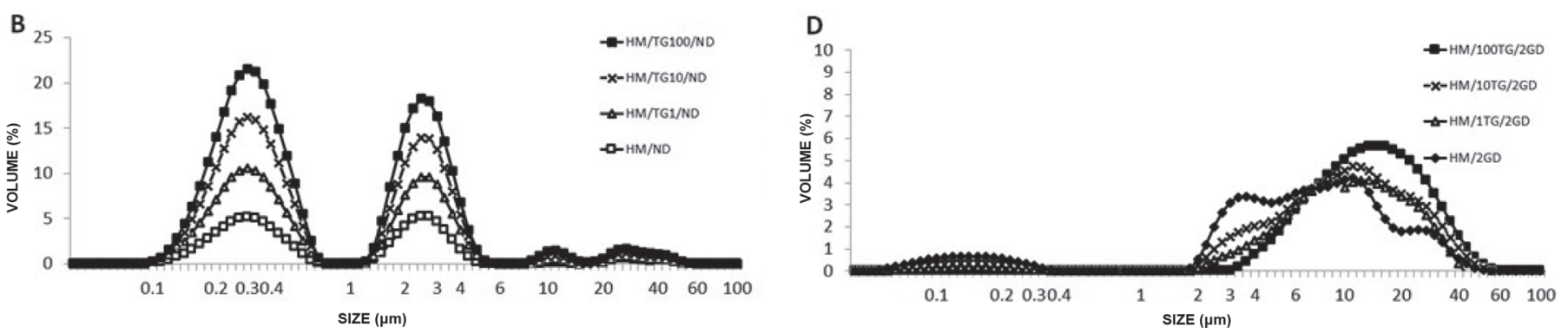

Figure 3. Particle size distribution of undigested cow milk (A; CM) and horse milk (B; HM), and gastrically digested CM (C) and HM (D), with different doses of transglutaminase (TG; Ajinomoto Activa, Ajinomoto, Paris, France). ND = not digested; NP = not pasteurized; $2 \mathrm{GD}=$ samples gastrically digested for $2 \mathrm{~h}$; TG1, TG10, and TG100 = doses of TG (U) per $1 \mathrm{~g}$ of total protein. All samples were initially preheated $\left(125^{\circ} \mathrm{C}\right.$ for $\left.10 \mathrm{~min}\right)$. Values in the tables for each panel are expressed as the sums of the percentages in each category of particle sizes $(<1,1$ to 10 , or 10 to $100 \mu \mathrm{m}) \pm \mathrm{SD}$. Different lowercase letters $(\mathrm{a}-\mathrm{d})$ denote statistically significant differences $(P<0.05)$. 
$\mathrm{CM}+100 \mathrm{U}$ TG. We found that HM was characterized by 2.4-fold lower average IgE reactivity with human sera than $\mathrm{CM}$ after total digestion, whereas $\mathrm{HM}+100$ U TG was 2.8-fold lower than $\mathrm{CM}+100 \mathrm{U}$ TG. The residual average IgG reactivity after digestion for HM was 4.7-fold lower than that for $\mathrm{CM}$, and $\mathrm{HM}+100 \mathrm{U}$ TG was 9.4-fold lower than $\mathrm{CM}+100 \mathrm{U}$ TG.

\section{DISCUSSION}

Many aspects, such as protein content and profile, indicate that HM is a valuable matrix for creating hypoallergic products. In contrast to other ruminant milk, such as camel, goat, and sheep milk, HM proteins show low similarity to $\mathrm{CM}$ proteins, which is also reflected by different epitope patterns (Fiocchi et al., 2010). Horse milk is characterized by lower protein and fat contents than are found in CM, as shown in other studies (Uniacke-Lowe et al., 2010; Danków et al., 2012). Businco et al. (2000) claimed that HM, with appropriate modifications, can be regarded as a good substitute for HM for children with severe IgE-mediated CMA. Processing can change the allergenic capacity of food due to alterations in the epitopes of food proteins (Mills et al., 2009; Paschke, 2009). The structural and conformational changes induced by food processing, such as polymerization, might change the immunoreactivity and allergenicity of milk proteins (Stanic et al., 2010; Wróblewska et al., 2011). The differences in the molecular structure of agglomerates could possibly be an outcome of the TG inhibitor in bovine milk serum (Bönisch et al., 2007), which is not present in HM. Differences in the polymerization of proteins among different milks cannot always be explained by the rheomorphic nature
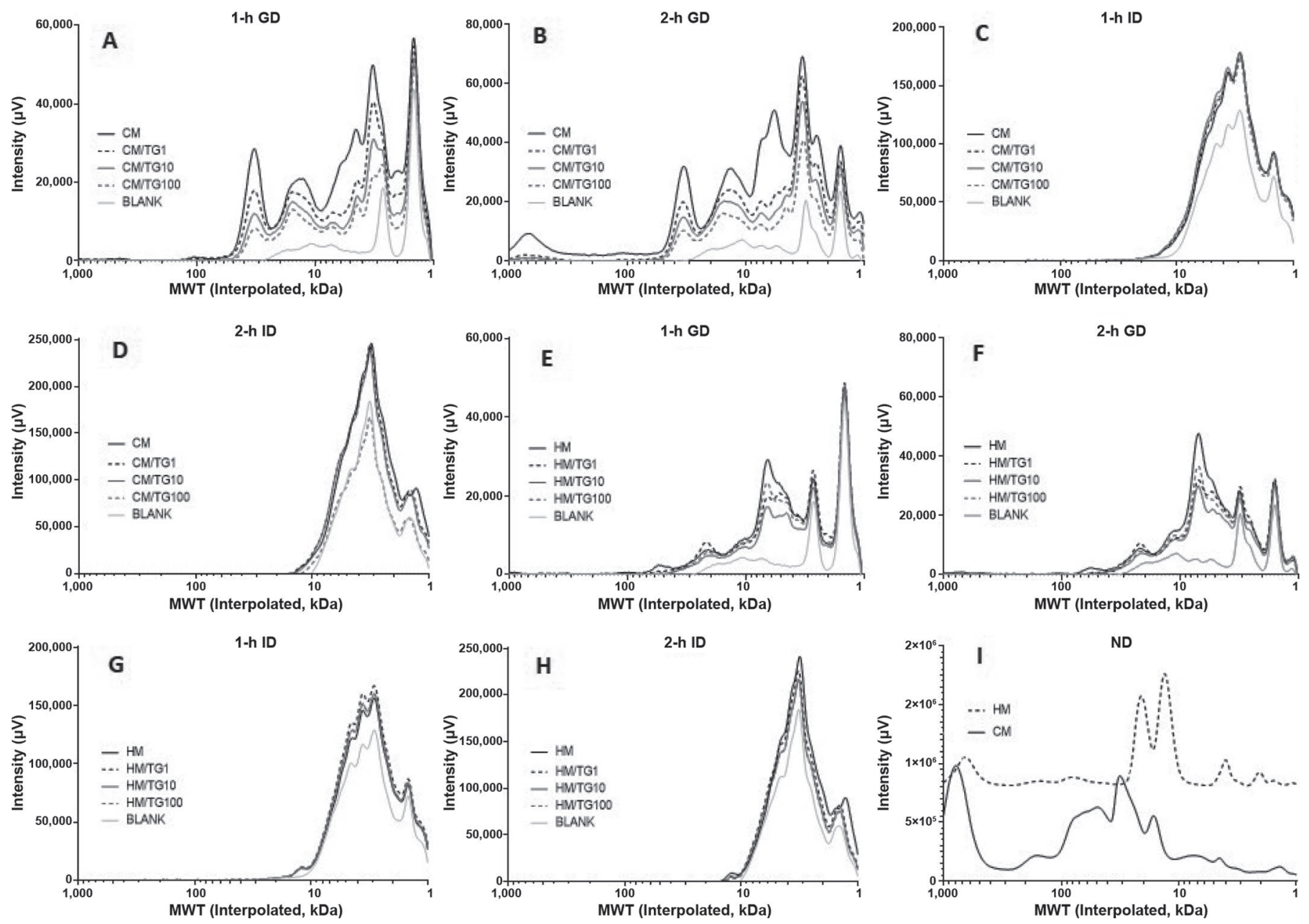

Figure 4. Interpolated kinetic profile of molecular weight (MWT) fractions of undigested (I) and digested cow milk (A through D) and horse milk (E through H) with different doses of transglutaminase (TG; Ajinomoto Activa, Ajinomoto, Paris, France), analyzed by size-exclusion chromatography (BioSep-SEC-S 2000; Phenomenex, Torrance, CA). CM = cow milk; HM = horse milk; ND = not digested; GD = gastric digestion; $\mathrm{ID}=$ intestinal digestion following 2-h GD; TG1, TG10, and TG100 = units of TG (U) per $1 \mathrm{~g}$ of total protein in the sample. (I) Undigested samples were centrifuged ( $15 \mathrm{~min}, 135 \times \mathrm{g}, 10^{\circ} \mathrm{C}$, Centrifuge $5424 \mathrm{R}$, Eppendorf, Hamburg, Germany) and filtrated $(0.22 \mu \mathrm{m})$. 
of proteins and the number of glutamine and lysine residues in each protein (Macierzanka et al., 2011).

The size of particles in food products is currently exploited in the food industry because size affects structure and allergenic properties (Mills and Mackie, 2008). An excessively large droplet could generate creaming due to poor stability, giving a product a greasy taste. On the other hand, an excessively small droplet may lead to flocculation. From a physiological point of view, the size of a particle considered an allergen can affect the absorbance in the intestine and exposure of the epitope to the immune system and can stimulate the synthesis of an allergen-specific reaction. Milk is an emulsion of fat globules surrounded by a membrane consisting of phospholipids and proteins within a water-based fluid. The differences detected in the particle size distribution analysis could be explained by the differences in the size of fat globules in CM and HM. According to Ménard et al. (2010), individual globules of fat in buffalo milk and $\mathrm{CM}$ were $4.93 \pm 0.04$ and $3.56 \pm 0.15 \mu \mathrm{m}$, respectively. Our results are in agreement with El-Zeini (2006), who reported that milk with a high fat content usually contains larger fat globules than milk with a low fat content. The results of the microscope analysis supported the particle size results. Horse milk contains smaller fat globules than does CM (Supplemental Figure S2; https: //doi.org/10.3168/jds.2019-17264). This has also been shown to affect the digestion of milk proteins (Hussein et al., 2015). Studies assessing resistance to digestive enzymes in food samples show that cross-linking can decrease digestibility (de Souza et al., 2009; Hiller and Lorenzen, 2009). In this study on CM and HM samples,

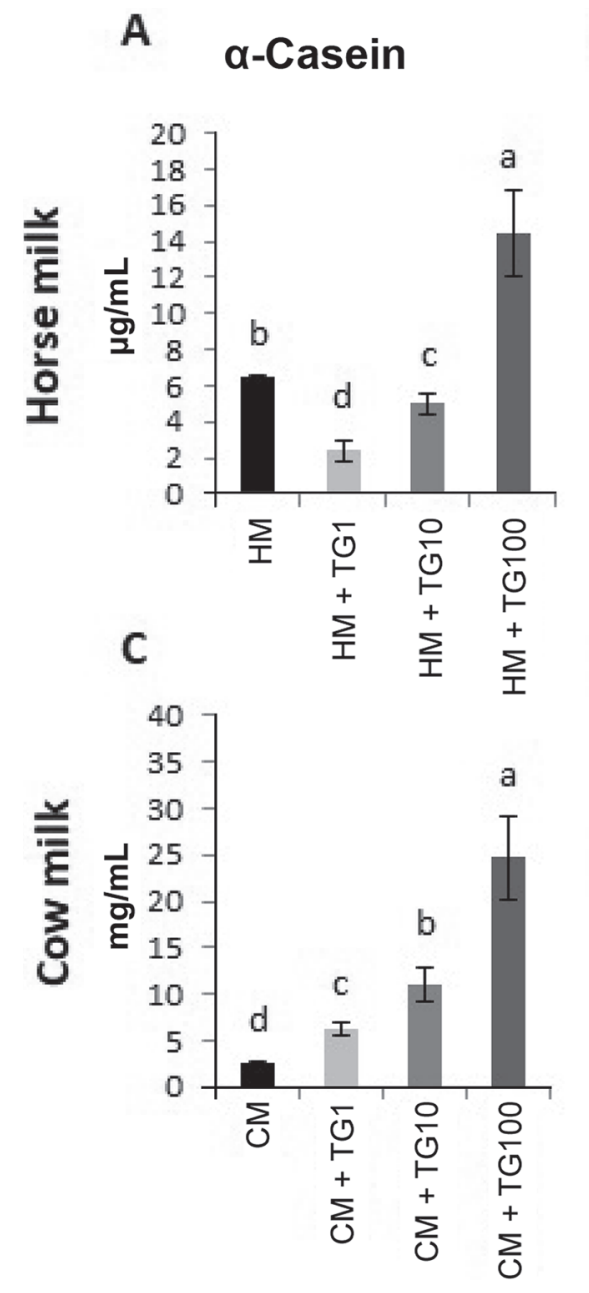

B

\section{$\beta$-Lactoglobulin}
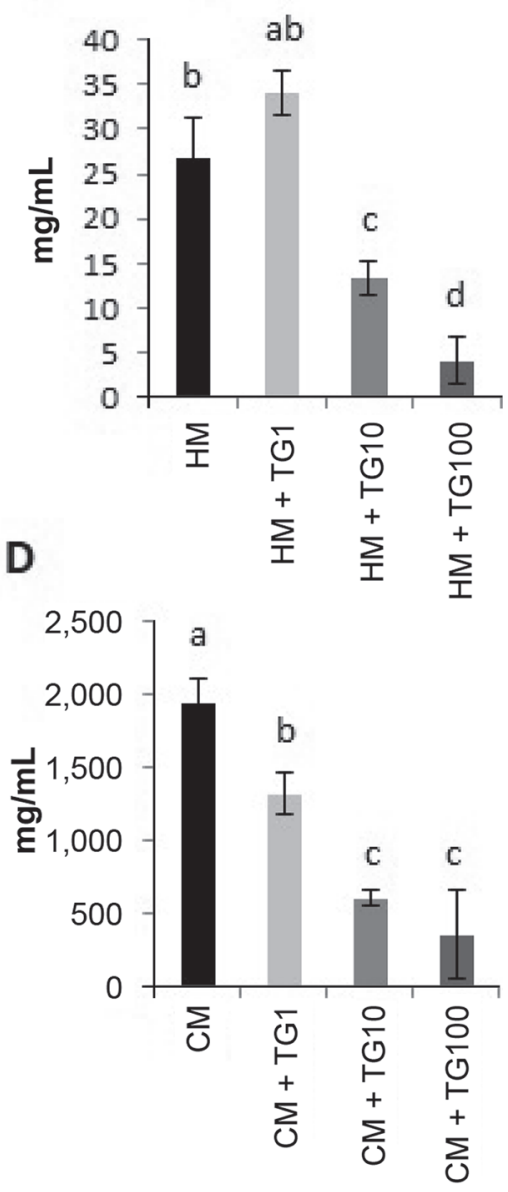

Figure 5. Immunoreactivity of $\alpha-\mathrm{CN}(\mathrm{A}, \mathrm{C})$ and $\beta$-LG (B, D) from undigested horse $(\mathrm{A}, \mathrm{B})$ and cow milk $(\mathrm{C}, \mathrm{D})$ with addition of microbial transglutaminase (TG; Ajinomoto Activa, Ajinomoto, Paris, France). 1TG, 10TG, and 100TG = activity units (U) of TG per $1 \mathrm{~g}$ of total protein in the sample; $\mathrm{CM}=$ cow milk; $\mathrm{HM}=$ horse milk. Different lowercase letters denote statistically significant differences $(P<0.05)$. Error bars indicate SEM. 


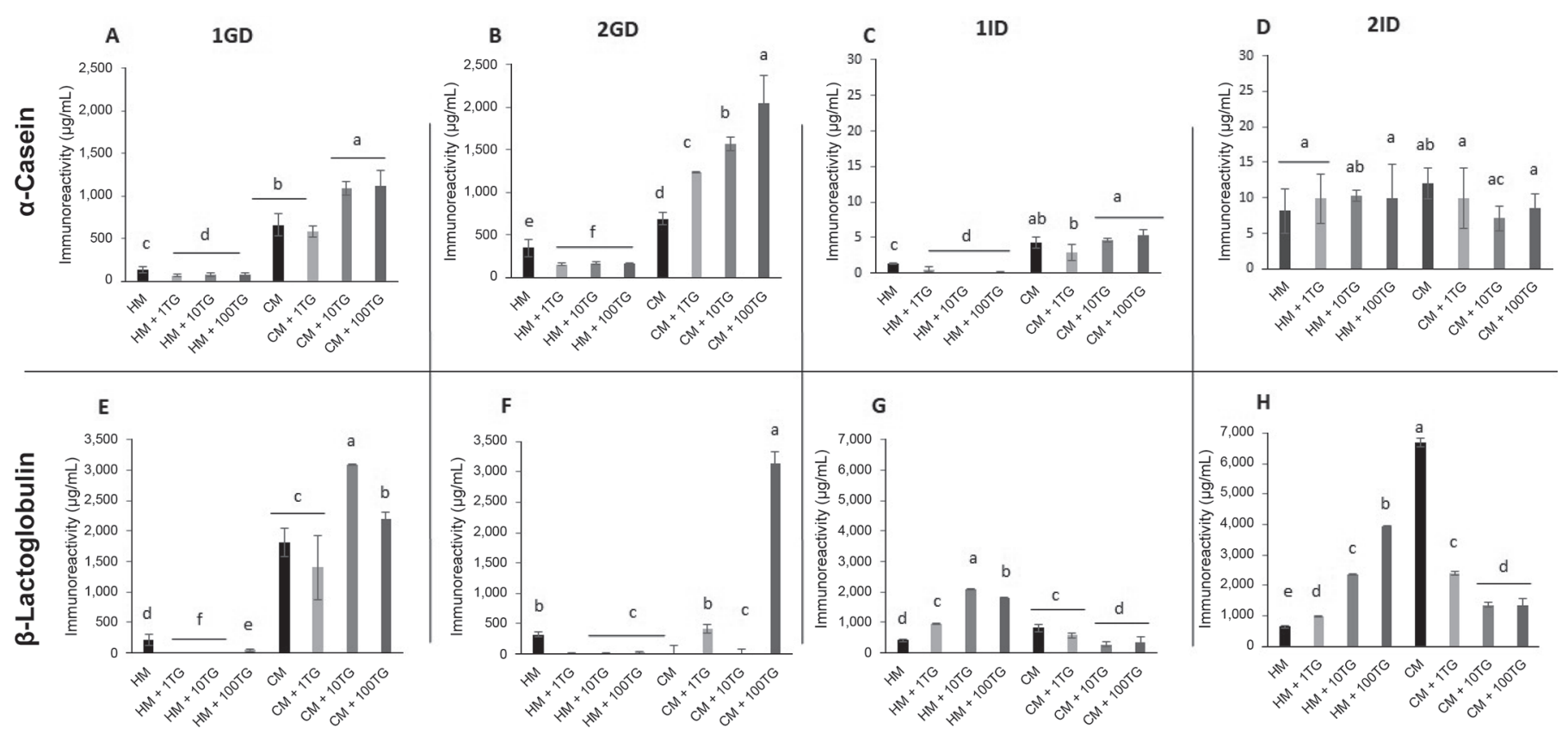

Figure 6. Kinetic profiles of the immunoreactivity of $\alpha-\mathrm{CN}$ (A through $\mathrm{D}$ ) and $\beta$-LG (E through $\mathrm{H})$ in digested horse milk (HM) and cow milk (CM) with different amounts of microbial transglutaminase (TG). TG1, TG10, and TG100 = amounts of enzyme, calculated as units (U) per $1 \mathrm{mg}$ of total protein in the sample; $1 \mathrm{GD}=$ measurement after $1 \mathrm{~h}$ of gastric digestion $(\mathrm{A}, \mathrm{E}) ; 2 \mathrm{GD}=$ measurement after $2 \mathrm{~h}$ of gastric digestion $(\mathrm{B}, \mathrm{F}) ; 1 \mathrm{ID}=$ measurement after $2 \mathrm{GD}$ and $1 \mathrm{~h}$ of intestinal digestion $(\mathrm{C}, \mathrm{G}) ; 2 \mathrm{ID}=$ measurement after total digestion, $2 \mathrm{GD}$ and $2 \mathrm{~h}$ of intestinal digestion (D, H). All samples were heated for 10 min at $125^{\circ} \mathrm{C}$ and incubated with Ajinomoto Activa (Ajinomoto, Paris, France) TG $\left(37^{\circ} \mathrm{C}, 18 \mathrm{~h}\right)$. Different lowercase letters denote statistically significant differences $(P<0.05)$. Error bars indicate SEM.

the large agglomerates assembled by TG were difficult to break down into smaller particles with the simulation of gastric digestive processes.

Major food allergens share several common features, and one shared feature is the relative stability in the presence of acid and proteases (Mandalari et al., 2009). Resistance to in vivo digestion is considered a predictive factor in assessing the allergenic potential of a protein to induce an allergic reaction in susceptible individuals. It is essential to evaluate the digestion process of proteins within the matrix in which they are usually consumed, not that of the isolated protein, especially in the field of food allergy. Havenaar et al. (2013) indicated that the in vitro digestion of caseinate treated with TG does not result in the formation of pepsin-resistant peptides (with a molecular mass $>4 \mathrm{kDa}$ ), whereas digestion of unmodified caseinate resulted in the formation of these fragments. Grimshaw et al. (2003) showed that the food matrix has a critical influence on allergen availability. Therefore, in vitro study in the whole food matrix has been undertaken in this research, to directly compare the gastric and intestinal digestive characteristics of $\mathrm{CM}$ and HM protein immunoreactivity. We studied $\beta$-LG and $\alpha-\mathrm{CN}$ because they are 2 of the most allergenic proteins in CM (Natale et al., 2004; Wróblewska et al., 2011). The matrix components may contribute to the ability of a protein to reach the sites of active immune sampling in the gastrointestinal mucosa and, thus, could influence its potential allergenicity (Teuber, 2002). Certainly the lower content of casein fractions, major allergenic proteins, in HM than in CM may at least partly explain the lower immunoreactivity of HM. Cow milk contains approximately $10 \mathrm{~g} / \mathrm{L}$ of $\alpha_{\mathrm{S} 1}-\mathrm{CN}$, the dominant fraction, and contains $\alpha_{\mathrm{S}_{2}} \mathrm{CN}$ at $3.7 \mathrm{~g} / \mathrm{L}$. Horse milk is characterized by a low concentration of these proteins, namely $2.5 \mathrm{~g} / \mathrm{L}$ of $\alpha_{\mathrm{S1}^{-}} \mathrm{CN}$ and $0.2 \mathrm{~g} / \mathrm{L}$ of $\alpha_{\mathrm{S} 2}$-CN (Miranda et al., 2004).

In this study, we showed that polymerization with TG decreased $\beta$-LG immunoreactivity of $\mathrm{HM}$ and CM. These results are in agreement with the results of a study by Villas-Boas et al. (2010), which previously showed that polymerization with TG modified or hid epitopes, reducing the potential antigenicity of $\beta$-LG in the presence of cysteine. Furthermore, the polymerization of chemically denatured $\beta-\mathrm{LG}$ with TG facilitated the action of gastrointestinal enzymes, and the digested products of chemically denatured $\beta-L G$ presented lower antigenic properties than did those of the untreated protein (Villas-Boas et al., 2012). In our study, after total digestion, TG cross-linking did not change the immunoreactivity of $\alpha-\mathrm{CN}$ but affected the immunoreactivity of $\beta-\mathrm{LG}$, which increased in $\mathrm{HM}$ and decreased in CM. The results of ELISA showed that post-digestion immunoreactivity remained; in some 
cases, immunoreactivity decreased, and in some cases, it was even enhanced. As seen from the study results, the reduction in allergenicity was still insufficient to obtain hypoallergic products. In our study, we showed that patients with CMA can develop a specific response to different protein fractions. Patients with CMA are often sensitized to several different proteins. We showed that appropriate processing with TG can decrease the immunoreactivity of specific HM proteins, such as $\beta-L G$. This finding may be important for patients with a strong immune system reaction to a defined protein fraction.

Our results showed that HM was less reactive with human allergic patient sera than was CM. The use of high temperature during milk processing is an indispensable technological process aimed at ensuring microbiological quality. Clinical trials have reported that almost $75 \%$ of children with IgE-mediated CMA may tolerate baked foods containing milk, such as muffins, cakes, breads, and waffles (Nowak-Wegrzyn et al., 2008). Heat treatment altered serum response of individual patients to $\mathrm{HM}$ and $\mathrm{CM}$, possibly caused by the destruction or masking of some epitopes, as has been observed in other studies (Rahaman et al., 2016). In most cases, TG cross-linking does not change the $\operatorname{IgE}$ and $\operatorname{IgG}$ signal from the allergic sera obtained in response to undigested samples. However, the observation of slight variations in the signal cannot be ignored, particularly in the prediction of clinical symptoms. Sampson (2001) found that in $95 \%$ of patients with milk-specific $\operatorname{IgE}$ levels above $15 \mathrm{kUA} / \mathrm{L}$, clinical symptoms can be expected during an oral challenge. In the present study, covalent molecular polymerization with TG increased the immune $\operatorname{IgE}$ and $\mathrm{IgG}$ reactions of sera from allergic patients to CM after total digestion, whereas almost no signal was detected from HM. The results from the assay with human sera showed that in patients with CMA, the response to analyzed milk proteins varies; therefore, a personalized diet should be designed for patients with CMA.

\section{CONCLUSIONS}

Polymerization with microbial TG, which induced conformational changes in proteins, modulates the exposure of $\mathrm{CM}$ and $\mathrm{HM}$ protein epitopes and their
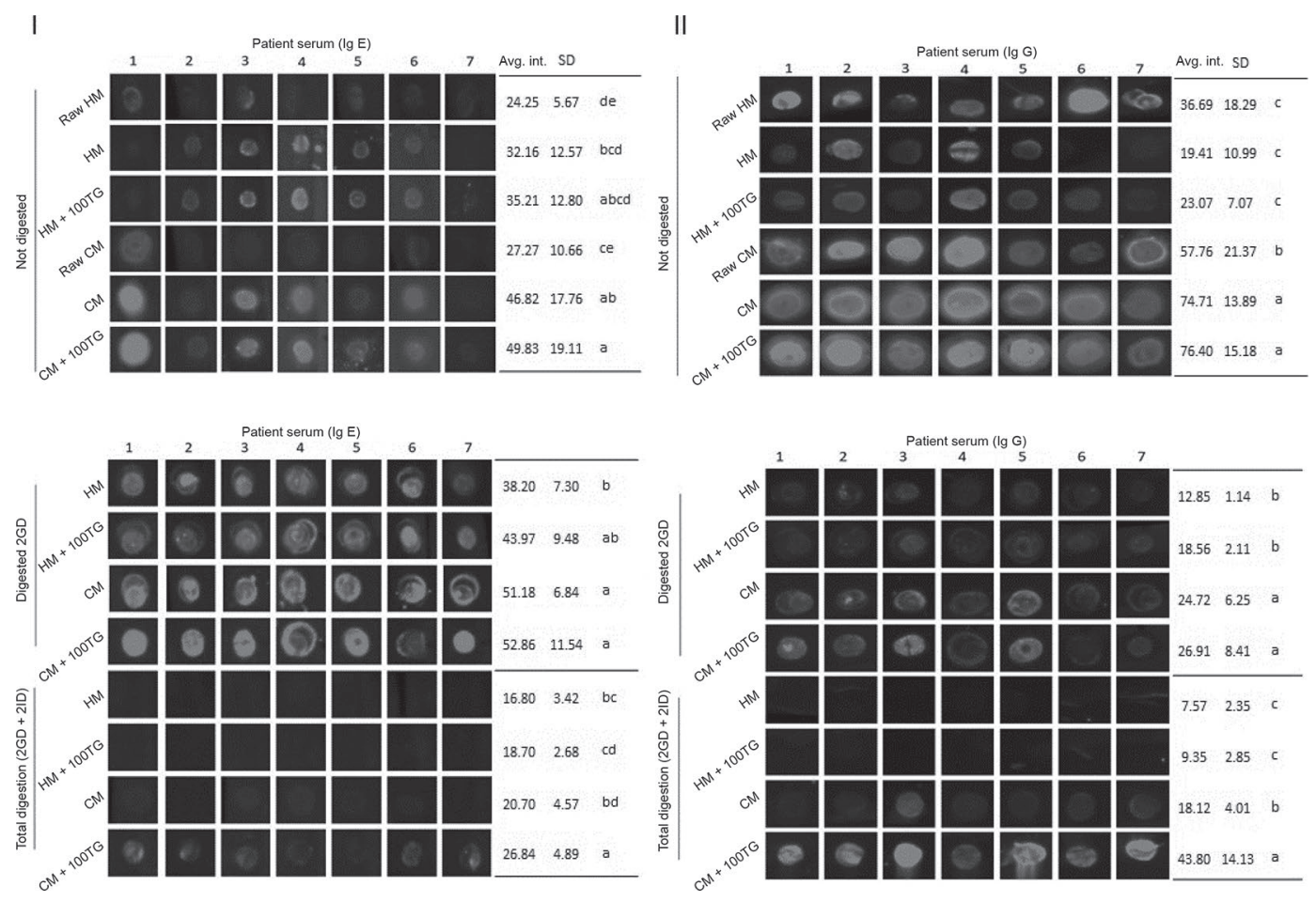

Figure 7. Immunodot analysis of specific IgE (I) and IgG (II) in samples before, during, and after in vitro digestion. $\mathrm{CM}=$ cow milk; HM $=$ horse milk; Raw $=$ unprocessed sample; $\mathrm{TG}=$ Ajinomoto Activa (Ajinomoto, Paris, France) microbial transglutaminase; 100TG $=$ the amount of enzyme, calculated as $100 \mathrm{U} / 1 \mathrm{mg}$ of total protein in sample; $2 \mathrm{GD}=$ measurement after $2 \mathrm{~h}$ of gastric digestion; 2ID = measurement after $2 \mathrm{GD}$ and $2 \mathrm{~h}$ of intestinal digestion; Avg. int. = mean intensity of dots from all patients' sera, \pm SD. All samples with TG were heat pretreated $\left(10 \mathrm{~min}\right.$ at $\left.125^{\circ} \mathrm{C}\right)$ and incubated with TG $\left(37^{\circ} \mathrm{C}, 18 \mathrm{~h}\right)$. Samples were normalized to similar protein contents. Samples with HM were diluted 1:4 ( $\mathrm{vol} / \mathrm{vol}$ ), and samples with CM were diluted 1:8 (vol/vol). Values followed by the same lowercase letter (a-e) within the same step of digestion are not significantly different $(P \leq 0.05)$. 
Table 2. The IgE and IgG reactivity normalized to the dilution based on immunodot analysis of samples before, during and after in vitro digestion $^{1}$

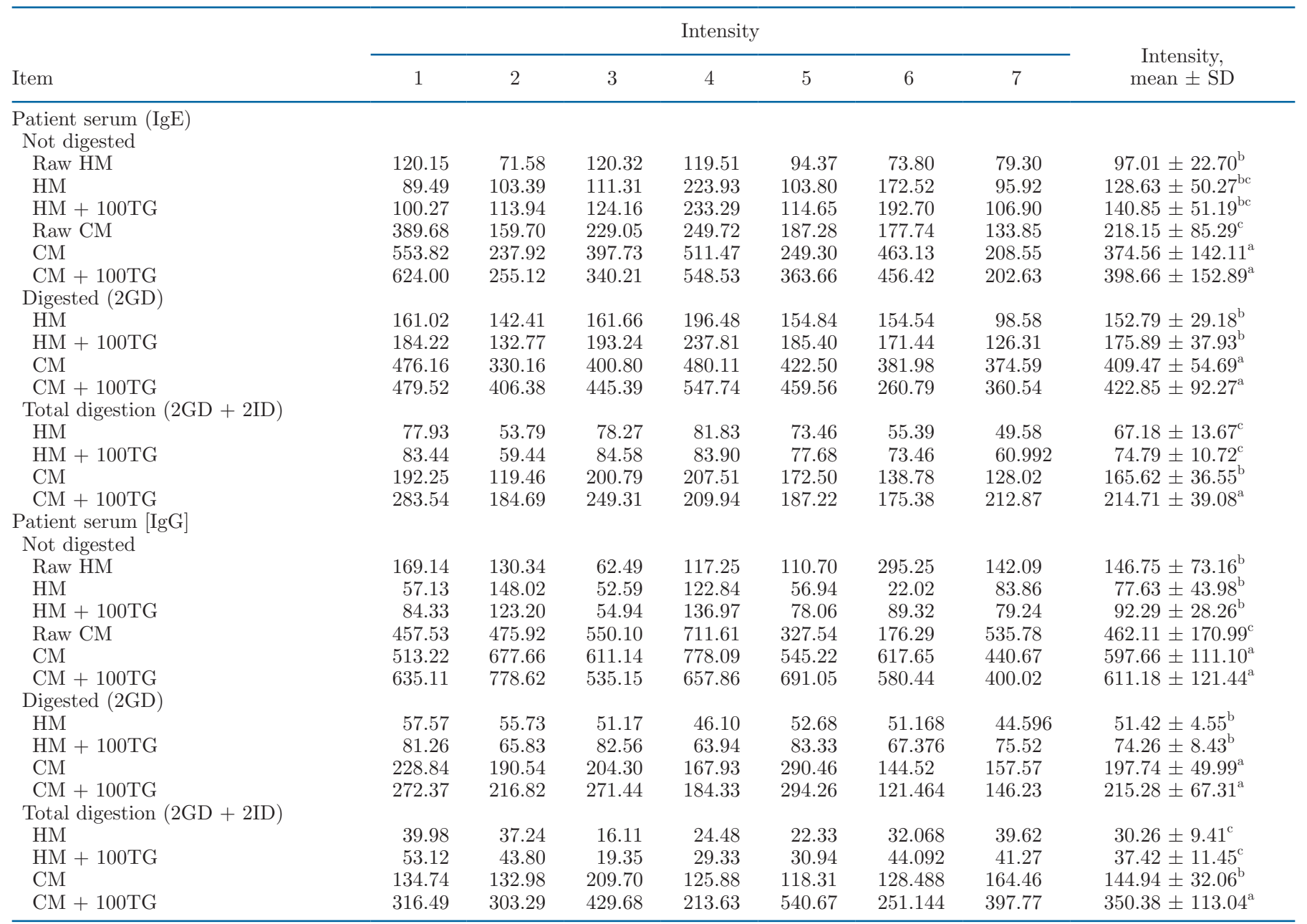

${ }^{\mathrm{a}-\mathrm{f}}$ Values followed by the same letter within the same step of digestion are not significantly different $(P \leq 0.05)$.

${ }^{1} \mathrm{CM}=$ cow milk (dilution, 1:8, vol/vol); $\mathrm{HM}=$ horse milk (dilution, 1:4, vol/vol); Raw = unprocessed sample; TG = microbial transglutaminase (Ajinomoto Activa, Ajinomoto, Paris, France); 100TG = amount of enzyme, calculated as $100 \mathrm{U} / \mathrm{mg}$ of total protein in the sample; 2GD = measurement after $2 \mathrm{~h}$ of gastric digestion; $2 \mathrm{ID}=2 \mathrm{~h}$ of intestinal digestion; Avg. int. = mean intensity of dots from all patient sera. All samples with $\mathrm{TG}$ were heat pretreated $\left(10 \mathrm{~min}\right.$ at $\left.125^{\circ} \mathrm{C}\right)$ and incubated $\left(37^{\circ} \mathrm{C}, 18 \mathrm{~h}\right)$.

recognition by elements of the immune system. Linking of TG modulates the level of immunoreactivity of the studied HM proteins based on the quantity of the enzyme and the type of protein. The highest amount of enzyme (100 U of TG) increased the immunoreactivity of $\alpha-\mathrm{CN}$ and decreased the immunoreactivity of $\beta$-LG, in both HM and CM. After digestion, HM was characterized by 2.4 -fold lower average $\mathrm{IgE}$ and 4.8 -fold lower IgG reactivity than CM with patients' sera. In this study, patient-specific differences in serum $\operatorname{IgE}$ and IgG signals were observed. Future research in this area should focus on HM processing techniques that result in the destruction of additional allergenic epitopes using combined techniques, such as cross-linking and lactic acid fermentation, to develop novel protein food materials with low immunogenic properties. Continued work on new methods of processing dairy food proteins will be of critical importance for decreasing the allergenicity of novel food proteins. The application of cross-linking with TG could reduce the allergenicity of some milk proteins and might be useful in producing "allergoids" for desensitization immunotherapy during individualized designed treatment.

\section{ACKNOWLEDGMENTS}

This study was supported by the National Science Center (Warsaw, Poland, No. UMO-2015/17/N/ NZ9/03666), a grant from KNOW Consortium (National Scientific Leadership Center, Warsaw, Poland) 
"Healthy Animal-Safety Food" (MS\&HE; Decision No. 05-1/KNOW2/2015) and the statutory fund of the Department of Immunology and Food Microbiology, Institute of Animal Reproduction and Food Research, Polish Academy of Sciences, Olsztyn. The authors thank Genactiv Co. (Poznań, Poland) for the horse milk. The authors declare that there are no conflicts of interest.

\section{REFERENCES}

Bönisch, M. P., S. Lauber, and U. Kulozik. 2007. Improvement of enzymatic cross-linking of casein micelles with transglutaminase by glutathione addition. Int. Dairy J. 17:3-11. https://doi.org/10 .1016/j.idairyj.2006.01.007.

Bradford, M. M. 1976. A rapid and sensitive method for the quantitation of microgram quantities of protein utilizing the principle of protein-dye binding. Anal. Biochem. 72:248-254. https://doi.org/ 10.1016/0003-2697(76)90527-3.

Businco, L., P. G. Giampietro, P. Lucenti, F. Lucaroni, C. Pini, G. Di Felice, P. Iacovacci, C. Curadi, and M. Orlandi. 2000. Allergenicity of mare's milk in children with cow's milk allergy. J. Allergy Clin. Immunol. 105:1031-1034. https://doi.org/10.1067/mai.2000 .106377 .

Cabrera-Chávez, F., O. Rouzaud-Sández, N. Sotelo-Cruz, and A. M. Calderón de la Barca. 2009. Bovine milk caseins and transglutaminase-treated cereal prolamins are differentially recognized by IgA of celiac disease patients according to their age. J. Agric. Food Chem. 57:3754-3759. https://doi.org/10.1021/jf802596g.

Danków, R., J. Pikul, N. Osten-Sacken, and J. Teichert. 2012. Charakterystyka i właściwości prozdrowotne mleka klaczy (Characteristics and salubrious properties of mare milk). Nauka Przyr. Tech. 6:16.

de Jong, G. A. H., G. Wijngaards, and S. J. Koppelman. 2003. Transglutaminase inhibitor from milk. J. Food Sci. 68:820-825. https:// doi.org/10.1111/j.1365-2621.2003.tb08249.x.

de Souza, C. F. V., J. G. Venzke, S. H. Flôres, and M. A. Z. Ayub. 2009. Nutritional effects of mechanically deboned chicken meat and soybean proteins cross-linking by microbial transglutaminase. Food Sci. Technol. Int. 15:337-344. https://doi.org/10.1177/ 1082013209346369.

El-Zeini, H. M. 2006. Microstructure, rheological and geometrical properties of fat globules of milk from different animal species. Pol. J. Food Nutr. Sci. 15:147-153.

Fiocchi, A., J. Brozek, H. Schünemann, S. L. Bahna, A. von Berg, K. Beyer, M. Bozzola, J. Bradsher, E. Compalati, M. Ebisawa, M. A. Guzman, H. Li, R. G. Heine, P. Keith, G. Lack, M. Landi, A. Martelli, F. Rance, H. Sampson, A. Stein, L. Terracciano, and S. Vieths. 2010. World Allergy Organization (WAO) Diagnosis and Rationale for Action against Cow's Milk Allergy (DRACMA) guidelines. Pediatr. Allergy Immunol. 21(Suppl. 21):1-125. https:/ /doi.org/10.1111/j.1399-3038.2010.01068.x.

Fotschki, J., A. Szyc, and B. Wróblewska. 2015a. Immunoreactivity of lactic acid-treated mare's milk after simulated digestion. J. Dairy Res. 82:78-85. https://doi.org/10.1017/S0022029914000612.

Fotschki, J., A. M. Szyc, J. M. Laparra, L. H. Markiewicz, and B. Wróblewska. 2016. Immune-modulating properties of horse milk administered to mice sensitized to cow milk. J. Dairy Sci. 99:93959404. https://doi.org/10.3168/jds.2016-11499.

Fotschki, J., A. M. Szyc, J. M. Laparra, and B. Wróblewska. 2015b. Mare's and cow's milk: Promote similar metabolic effects and expression of innate markers in Caco-2 cells? Food Res. Int. 72:184190. https://doi.org/10.1016/j.foodres.2015.04.001.

Giosafatto, C. V. L., N. M. Rigby, N. Wellner, M. Ridout, F. Husband, and A. R. Mackie. 2012. Microbial transglutaminase-mediated modification of ovalbumin. Food Hydrocoll. 26:261-267. https:// doi.org/10.1016/j.foodhyd.2011.06.003.

Golkar, A., J. M. Milani, and T. Vasiljevic. 2019. Altering allergenicity of cow's milk by food processing for applications in infant formula.
Crit. Rev. Food Sci. Nutr. 59:159-172. https://doi.org/10.1080/ 10408398.2017.1363156.

Grimshaw, K. E. C., R. M. King, J. A. Nordlee, S. L. Hefle, J. O. Warner, and J. O. B. Hourihane. 2003. Presentation of allergen in different food preparations affects the nature of the allergic reaction-A case series. Clin. Exp. Allergy 33:1581-1585. https:// doi.org/10.1046/j.1365-2222.2003.01795.x.

Havenaar, R., A. de Jong, M. E. Koenen, J. van Bilsen, A. M. Janssen, E. Labij, and H. J. M. Westerbeek. 2013. Digestibility of transglutaminase cross-linked caseinate versus native caseinate in an in vitro multicompartmental model simulating young child and adult gastrointestinal conditions. J. Agric. Food Chem. 61:7636-7644. https://doi.org/10.1021/jf402824u.

Hiller, B., and P. C. Lorenzen. 2009. Functional properties of milk proteins as affected by enzymatic oligomerisation. Food Res. Int. 42:899-908. https://doi.org/10.1016/j.foodres.2009.04.022.

Hochwallner, H., U. Schulmeister, I. Swoboda, S. Spitzauer, and R. Valenta. 2014. Cow's milk allergy: From allergens to new forms of diagnosis, therapy and prevention. Methods 66:22-33. https://doi .org/10.1016/j.ymeth.2013.08.005.

Høst, A. 2002. Frequency of cow's milk allergy in childhood. Ann. Allergy Asthma Immunol. 89:33-37. https://doi.org/10.1016/S1081 $-1206(10) 62120-5$.

Huby, R. D. J. 2000. Why are some proteins allergens? Toxicol. Sci. 55:235-246. https://doi.org/10.1093/toxsci/55.2.235.

Hussein, M. O., C. L. Hoad, J. Wright, G. Singh, M. C. Stephenson, E. F. Cox, E. Placidi, S. E. Pritchard, C. Costigan, H. Ribeiro, E. Ciampi, A. Nandi, N. Hedges, P. Sanderson, H. P. F. Peters, P. Rayment, R. C. Spiller, P. A. Gowland, and L. Marciani. 2015. Fat emulsion intragastric stability and droplet size modulate gastrointestinal responses and subsequent food intake in young adults. J. Nutr. 145:1170-1177. https://doi.org/10.3945/jn.114.204339.

Kieliszek, M., and A. Misiewicz. 2014. Microbial transglutaminase and its application in the food industry. A review. Folia Microbiol. (Praha) 59:241-250. https://doi.org/10.1007/s12223-013-0287-x.

Laemmli, U. K. 1970. Cleavage of structural proteins during the assembly of the head of bacteriophage T4. Nature 227:680-685. https://doi.org/10.1038/227680a0.

Macierzanka, A., F. Bordron, N. M. Rigby, E. N. C. Mills, M. Lille, K. Poutanen, and A. R. Mackie. 2011. Transglutaminase cross-linking kinetics of sodium caseinate is changed after emulsification. Food Hydrocoll. 25:843-850. https://doi.org/10.1016/j.foodhyd.2010.07 .010 .

Mandalari, G., K. Adel-Patient, V. Barkholt, C. Baro, L. Bennett, M. Bublin, S. Gaier, G. Graser, G. S. Ladics, D. Mierzejewska, E. Vassilopoulou, Y. M. Vissers, L. Zuidmeer, N. M. Rigby, L. J. Salt, M. Defernez, F. Mulholland, A. R. Mackie, M. S. J. Wickham, and E. N. C. Mills. 2009. In vitro digestibility of $\beta$-casein and $\beta$-lactoglobulin under simulated human gastric and duodenal conditions: A multi-laboratory evaluation. Regul. Toxicol. Pharmacol. 55:372-381. https://doi.org/10.1016/j.yrtph.2009.08.010.

Markiewicz, L. H., A. Szymkiewicz, A. Szyc, and B. Wróblewska. 2016. A simultaneous two-colour detection method of human IgG- and IgE-reactive proteins from lactic acid bacteria. J. Microbiol. Methods 126:72-75. https://doi.org/10.1016/j.mimet.2016.05.007.

Ménard, O., S. Ahmad, F. Rousseau, V. Briard-Bion, F. Gaucheron, and C. Lopez. 2010. Buffalo vs. cow milk fat globules: Size distribution, zeta-potential, compositions in total fatty acids and in polar lipids from the milk fat globule membrane. Food Chem. 120:544-551. https://doi.org/10.1016/j.foodchem.2009.10.053.

Mills, E. N. C., and A. R. Mackie. 2008. The impact of processing on allergenicity of food. Curr. Opin. Allergy Clin. Immunol. 8:249253. https://doi.org/10.1097/ACI.0b013e3282ffb123.

Mills, E. N. C., A. I. Sancho, N. M. Rigby, J. A. Jenkins, and A. R. Mackie. 2009. Impact of food processing on the structural and allergenic properties of food allergens. Mol. Nutr. Food Res. 53:963969. https://doi.org/10.1002/mnfr.200800236.

Minekus, M., M. Alminger, P. Alvito, S. Ballance, T. Bohn, C. Bourlieu, F. Carrière, R. Boutrou, M. Corredig, D. Dupont, C. Dufour, L. Egger, M. Golding, S. Karakaya, B. Kirkhus, S. Le Feunteun, U. Lesmes, A. Macierzanka, A. Mackie, S. Marze, D. J. McClements, 
O. Ménard, I. Recio, C. N. Santos, R. P. Singh, G. E. Vegarud, M. S. J. Wickham, W. Weitschies, and A. Brodkorb. 2014. A standardised static in vitro digestion method suitable for food-An international consensus. Food Funct. 5:1113-1124. https://doi.org/ 10.1039/C3FO60702J.

Miranda, G., M.-F. Mahé, C. Leroux, and P. Martin. 2004. Proteomic tools to characterize the protein fraction of Equidae milk. Proteomics 4:2496-2509. https://doi.org/10.1002/pmic.200300765.

Natale, M., C. Bisson, G. Monti, A. Peltran, L. P. Garoffo, S. Valentini, C. Fabris, E. Bertino, A. Coscia, and A. Conti. 2004. Cow's milk allergens identification by two-dimensional immunoblotting and mass spectrometry. Mol. Nutr. Food Res. 48:363-369. https:/ /doi.org/10.1002/mnfr.200400011.

Nowak-Wegrzyn, A., K. A. Bloom, S. H. Sicherer, W. G. Shreffler, S. Noone, N. Wanich, and H. A. Sampson. 2008. Tolerance to extensively heated milk in children with cow's milk allergy. J. Allergy Clin. Immunol. 122:342-347. https://doi.org/10.1016/j.jaci 2008.05.043.

Olivier, C. E., R. P. Lima, D. G. Pinto, R. A. Santos, G. K. Silva, S. L. Lorena, M. B. Villas-Boas, F. M. Netto, and R. L. Zollner. 2012. In search of a tolerance-induction strategy for cow's milk allergies: Significant reduction of beta-lactoglobulin allergenicity via transglutaminase/cysteine polymerization: Allergoid generation by polymerization. Clinics (São Paulo) 67:1171-1179. https://doi .org/10.6061/clinics/2012(10)09.

Paschke, A. 2009. Aspects of food processing and its effect on allergen structure. Mol. Nutr. Food Res. 53:959-962. https://doi.org/10 $.1002 / \mathrm{mnfr} .200800187$.

Pedersen, M. H., T. K. Hansen, E. Sten, K. Seguro, T. Ohtsuka, A. Morita, C. Bindslev-Jensen, and L. K. Poulsen. 2004. Evaluation of the potential allergenicity of the enzyme microbial transglutaminase using the $2001 \mathrm{FAO} / \mathrm{WHO}$ decision tree. Mol. Nutr. Food Res. 48:434-440. https://doi.org/10.1002/mnfr.200400014.

Potočnik, K., V. Gantner, K. Kuterovac, and C. Angela. 2011. Mare's milk: Composition and protein fraction in comparison with different milk species. Mljekarstvo 61:107-113.

Rahaman, T., T. Vasiljevic, and L. Ramchandran. 2016. Effect of processing on conformational changes of food proteins related to allergenicity. Trends Food Sci. Technol. 49:24-34. https://doi.org/ 10.1016/j.tifs.2016.01.001.

Sabadin, I. S., M. B. Villas-Boas, R. de Lima Zollner, and F. M. Netto. 2012. Effect of combined treatment of hydrolysis and polymerization with transglutaminase on $\beta$-lactoglobulin antigenicity. Eur. Food Res. Technol. 235:801-809. https://doi.org/10.1007/s00217 -012-1802-z.

Sampson, H. A. 2001. Utility of food-specific IgE concentrations in predicting symptomatic food allergy. J. Allergy Clin. Immunol. 107:891-896. https://doi.org/10.1067/mai.2001.114708.

Schnell, S., and R. A. Herman. 2009. Should digestion assays be used to estimate persistence of potential allergens in tests for safety of novel food proteins? Clin. Mol. Allergy 7:1. https://doi.org/10 $.1186 / 1476-7961-7-1$.

Stanic, D., E. Monogioudi, D. Ercili, J. Radosavljevic, M. Atanaskovic-Markovic, O. Vuckovic, L. Raija, M. Mattinen, J. Buchert, and T. Cirkovic Velickovic. 2010. Digestibility and allergenicity assessment of enzymatically crosslinked $\beta$-casein. Mol. Nutr. Food Res. 54:1273-1284. https://doi.org/10.1002/mnfr.200900184.

Teuber, S. S. 2002. Hypothesis: The protein body effect and other aspects of food matrix effects. Ann. N. Y. Acad. Sci. 964:111-116. https://doi.org/10.1111/j.1749-6632.2002.tb04136.x.

Uniacke-Lowe, T., T. Huppertz, and P. F. Fox. 2010. Equine milk proteins: Chemistry, structure and nutritional significance. Int. Dairy J. 20:609-629. https://doi.org/10.1016/j.idairyj.2010.02.007.

Villas-Boas, M. B., M. A. Fernandes, R. D. L. Zollner, and F. M. Netto. 2012. Effect of polymerization with transglutaminase on in vitro digestion and antigenicity of $\beta$-lactoglobulin. Int. Dairy J. 25:123-131. https://doi.org/10.1016/j.idairyj.2012.02.007.

Villas-Boas, M. B., K. P. Vieira, G. Trevizan, R. de Lima Zollner, and F. M. Netto. 2010. The effect of transglutaminase-induced polymerization in the presence of cysteine on $\beta$-lactoglobulin antigenicity. Int. Dairy J. 20:386-392. https://doi.org/10.1016/j.idairyj 2010.01.004.

Wróblewska, B., A. Kaliszewska, P. Kołakowski, K. Pawlikowska, and A. Troszyńska. 2011. Impact of transglutaminase reaction on the immunoreactive and sensory quality of yoghurt starter. World J. Microbiol. Biotechnol. 27:215-227. https://doi.org/10.1007/ s11274-010-0446-z.

Wróblewska, B., A. Kaliszewska-Suchodoła, P. Kołakowski, and A. Troszyńska. 2013. The effect of microbial transglutaminase on the immunoreactive and sensory properties of fermented milk beverages. Int. J. Food Sci. Technol. 48:1007-1017. https://doi.org/10 $.1111 / \mathrm{ijfs} .12054$.

Wróblewska, B., P. Kołakowski, K. Pawlikowska, A. Troszyńska, and A. Kaliszewska. 2009. Influence of the addition of transglutaminase on the immunoreactivity of milk proteins and sensory quality of kefir. Food Hydrocoll. 23:2434-2445. https://doi.org/10.1016/j foodhyd.2009.06.023.

Wróblewska, B., L. H. Markiewicz, A. M. Szyc, M. A. Dietrich, A Szymkiewicz, and J. Fotschki. 2016. Lactobacillus casei LcY decreases milk protein immunoreactivity of fermented buttermilk but also contains IgE-reactive proteins. Food Res. Int. 83:95-101. https://doi.org/10.1016/j.foodres.2016.02.016.

\section{ORCIDS}

J. Fotschki @ https://orcid.org/0000-0002-0116-0909

B. Wróblewska ๑ https://orcid.org/0000-0002-7383-7819

B. Fotschki ๑ https://orcid.org/0000-0002-9727-7481 